\begin{tabular}{|c|c|c|}
\hline ل & International Journal of Current Research in & \\
\hline & Biosciences and Plant Biology & \\
\hline $\begin{array}{l}\text { EXCELLENT } \\
\text { PUBLISHERS }\end{array}$ & $\begin{array}{c}\text { ISSN: 2349-8080 (Online) • Volume } 3 \bullet \text { Number } 1 \text { (January-2016) } \\
\text { Journal homepage: www.ijcrbp.com }\end{array}$ & \\
\hline
\end{tabular}

Original Research Article

doi: $\underline{\text { http://dx.doi.org/10.20546/ijerbp.2016.301.010 }}$

\title{
Ethno-botanical Study of Selected Sacred Groves in Cuddalore and Villupuram Districts, Tamil Nadu, India
}

\author{
S. Karthik*, M. Subramanian, S. Ravikumar and R. Dhamotharan \\ P.G. and Research Department of Plant Biology and Plant Biotechnology, Presidency College (Autonomous), Kamarajar Road, \\ Chennai-60o 005, Tamil Nadu, India
}

*Corresponding author.

\begin{abstract}
An ethno-botanical study was carried out to document the medicinal plants in two districts of Cuddalore and Villupuram. The sacred groves of Dhanam (DM), Edaicheruvi (EI), Konalavadi (KI), Kuthanur (KR), M.Parur (MR), Murarbad (MD), Pallavadi (PI), Siruvambur (SR), Udaiyanachi (UI), V.Palaiyam (VM), Veerapaiyangara (VIM), Visalur (VR) were studied. 94 medicinal plant species were identified. The plants include trees (38\%), shrubs (5\%), herbs (26\%), and climbers (1\%), parasites (2\%) and lianas (28\%). A total of 94 identified plant species belonged to 84 genera and 47 families. Sacred groves are a small area of forest protected by the local people. It is one of the rich biodiversity spots wherein rare plants, animal, and medicinal plants are established in reserved forests. The local people believe that their ancestors have been lived in the grove. That is the major reason that has been observed in the present study that the local people are not taking the fallen trees and twigs from the sacred groves.
\end{abstract}

\section{Article Info}

Accepted: 21 December 2015

Available Online: 06 January 2016

\section{Ke ywords}

Diseases

Ethnobotany

Sacred groves

Traditional knowledge

\section{Introduction}

The knowledge of ethno-botany predates the history of civilization. The ancient people, by a process of trial and error, had classified edible and non edible plants growing in the forest. However, the information available on this subject is meager and the study of ethnobotany is still in infancy. It has been established that the study of ethnobotany can play an important role in both scientific and socio-cultural studies. The ancient Indian medical system of Ayurveda has studied the medicinal properties of plants. Even modern medicine has adopted some of the plants and their extracts recommended by Ayurveda. India due to its diversity of soil and climatic conditions plays host to a number of medicinal plants. To list a few species among them are: tulsi, neem, amla, hibiscus, curry leaf, coriander, ginger, capsicum, pepper, garlic, onion, tonebreaker, black night shade plant, five-leave chaste tree, castor oil plant, cuscus grass, fenugreek, drumstick, datura, henna, Adathoda, gloriosa lily, spiny amaranth, beetle leaf, Indian aloe and Bermuda grass, etc. (Rajkuamr et al., 2014).

The sacred groves are a unique repository of rare species and medicinal plants which have been preserved through the ages due to ancient customs, taboos and respect for nature. The local communities themselves manage the sacred groves. Thus, the sacred groves represent the most important ecological tradition of ancient India. The sacred groves contain the ancient secrets and remedies of herbs and traditional medicine. There is a felt need to document this vast knowledge that is available in the sacred groves. Thus, the study of ethno-botany assumes much significance (Amirthalingam, 2012).

India has more than three thousand years of experience of experimenting with medicinal plants. All sections of the population have made use of these folk medications. 
The local communities depend on the sacred groves not only for their medicinal needs but also for timber, wood and non-timber forest products (Pushpangadan, 1995). This knowledge of traditional medicine has largely been forgotten due to the quick results shown by the allopathic medicines. However, in recent times, this traditional knowledge is being revived and has an increasing number of adherents. The present study was carried out with the objective of documenting the indigenous medicinal plants used by the local communities for the treatment of various illnesses.

\section{Materials and methods}

\section{Study Area}

For the purpose of the study twelve sacred groves from Cuddalore and Villupuram districts were selected. These include: Dhanam (DM), Edaicheruvi (EI), Konalavadi (KI), Kuthanur (KR), M.Parur (MR), Murarbad (MD), Pallavadi (PI), Siruvambur (SR), Udaiyanachi (UI),
V.Palaiyam (VM), Veerapaiyangara (VIM) and Visalur (VR) (Fig. 1).

\section{Data collection}

Knowledge of medicinal plants was obtained from the local communities who have imbibed many generations of knowledge on this subject. Documentation of medicinal plants was gathered from the local people who were having a treasure of knowledge on medicinal plants. Plants were collected and identified using the standard Floras of Gamble (1915-1936), Matthew (1982, 1983 and 1988), Nair and Henry (1983), Henry et al. (1987 and 1989), Sanjappa (1992), Balakrishnan and Chakrabarthy (2007), Karthikeyan et al. (2009) have also been referred for the correct botanical names for the specimens identified. The herbarium was also prepared for all the plants and has been deposited in the Presidency College, Chennai. The details of the plant including their vernacular name, useful part and medicinal uses were tabulated.

Fig. 1: Distribution of sacred grove study sites in Villupuram and Cuddalore districts of Tamil Nadu.

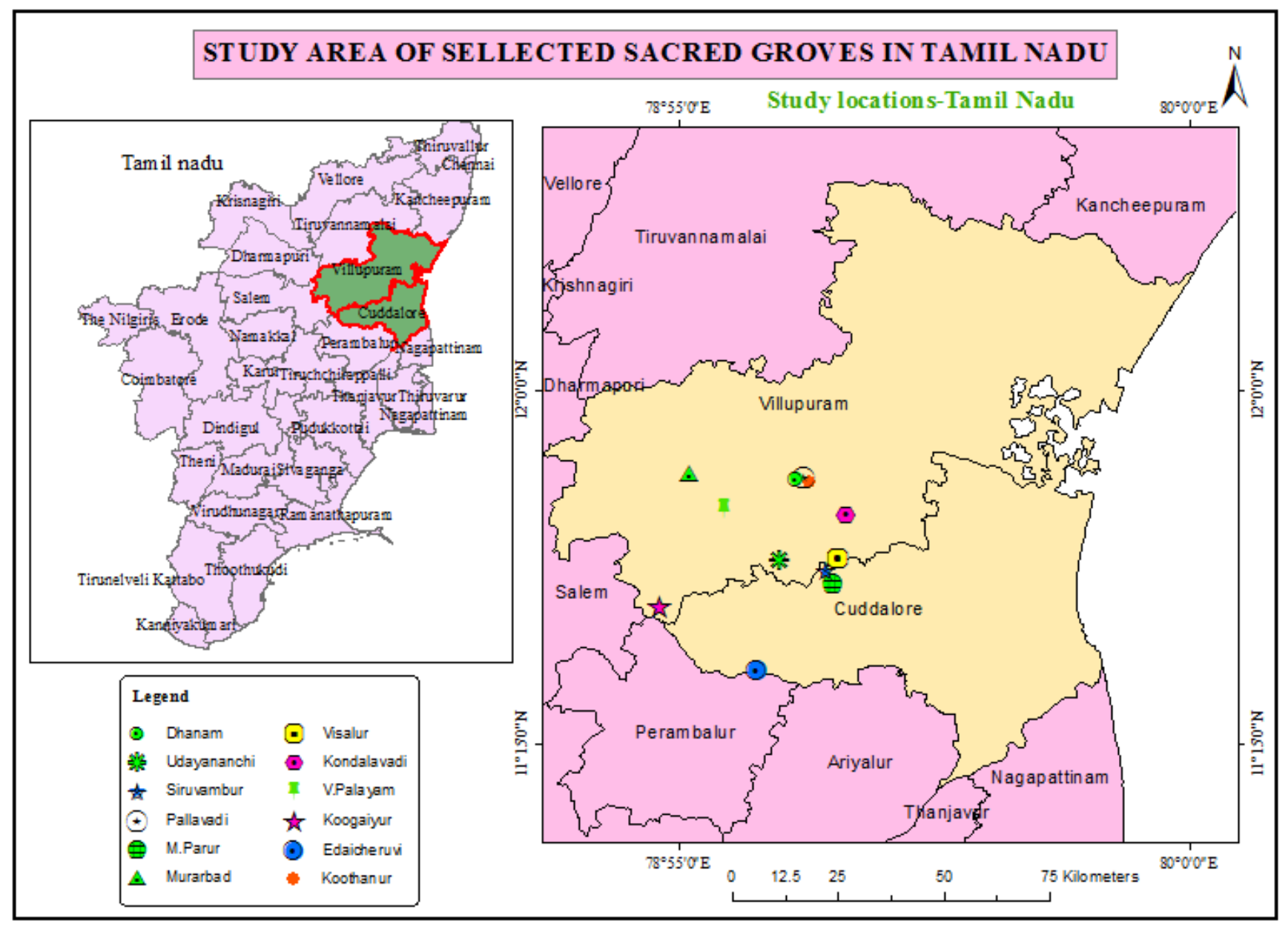




\section{Results}

A total of 94 medicinal plant species belonging to 47 families were collected from twelve sacred groves of the study area with the help of traditional healers and the local communities (Fig. 2). They were interviewed about the way of usage of plants as medicine for treating various diseases.

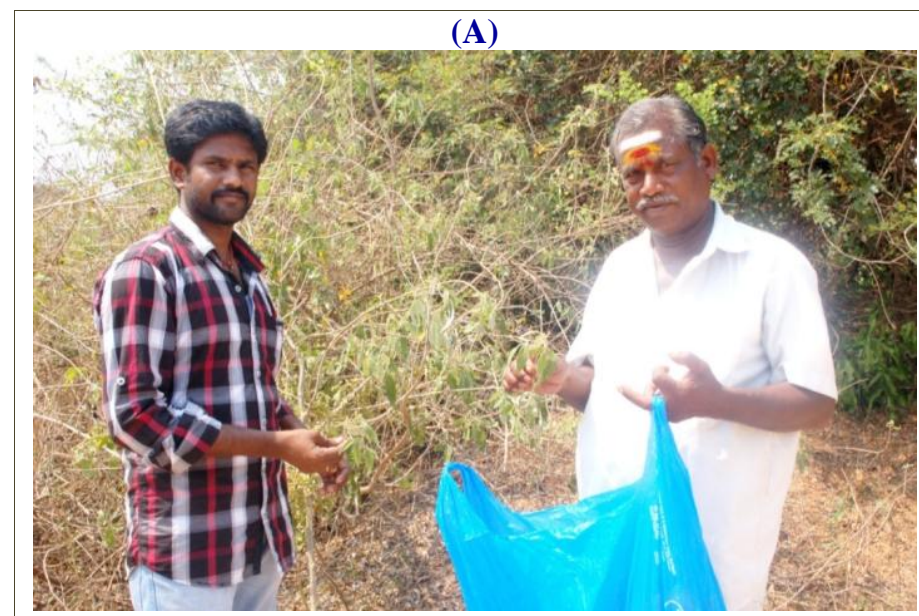

(C)

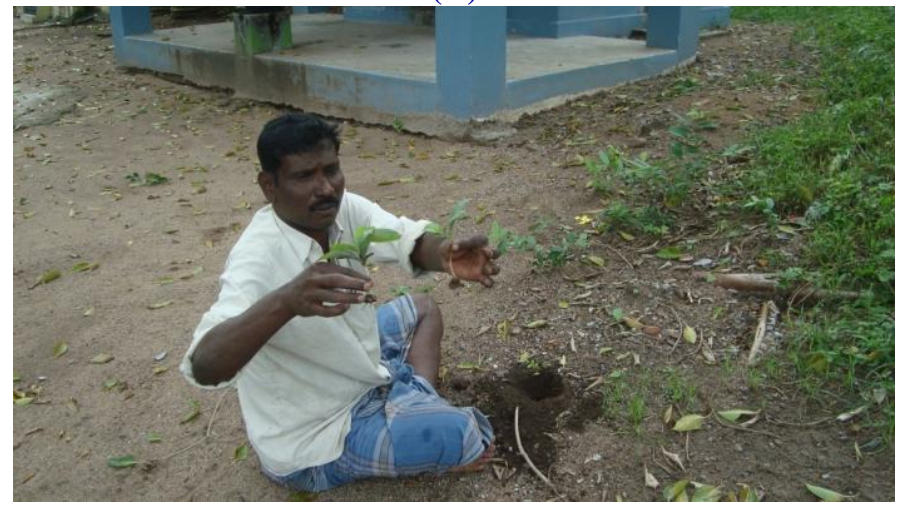

(B)

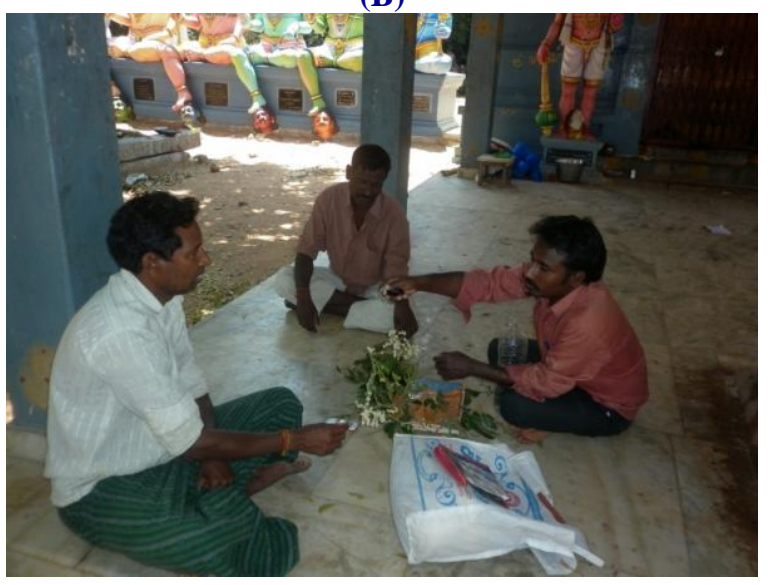

(D)

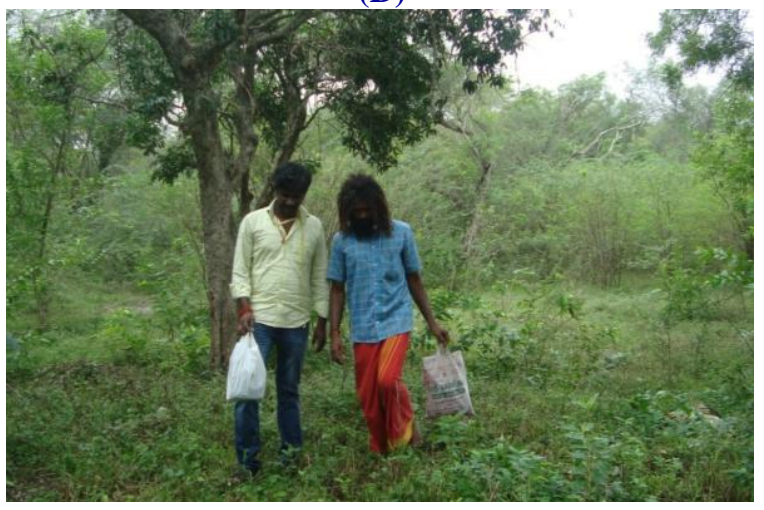

Fig. 2: (A) Local vaidya collecting plants for making medicine; (B) Interview with the local medicine man and documentation; (C) The traditional healer is collecting the tubers and other parts of plants from the grove; (D) The traditional healer is searching for tubers and medicinal plants in and around the sacred grove site.

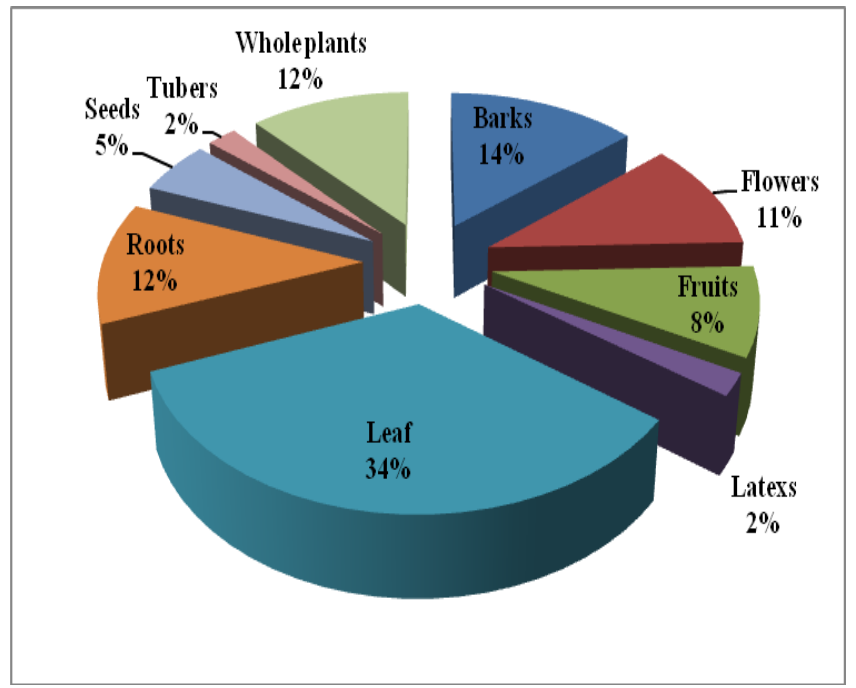

Fig. 3: Plant part-wise ethno-medicinal analysis.
The plant parts mostly reported in this regard were leaves (34\%), bark (14\%), whole plant and root (12\%), flower $(11 \%)$, fruits $(8 \%)$, seed $(5 \%)$, latex $(2 \%)$ and tuber $(2 \%)$ (Fig. 3). The availability of plant materials in the season time, whether used either in fresh form or as extract or paste or dried or powder or as an oil was also studied. The plants were used singly as only one plant or combined as more than one plant to treat the diseases and time to be taken for the treatment of disease either in a short period of time or over a longer period of time depending on the severity of the disease and the condition of the patient. Table 1 gives the details of the plants which were used to treat many diseases, particularly filariasis, diabetes, as an aphrodiasiac, or appetizer, for blood pressure, skin disease, gastric problems, haemorrhoids, kidney stone, lice killer, sexual activities, ulcer and dysentery. 
Table 1. Ethnomedicinal plants recorded from selected sacred groves in Cuddalore and Villupuram District, Tamil Nadu, India.

\begin{tabular}{|c|c|c|c|c|c|c|c|c|c|}
\hline $\begin{array}{l}\text { Sl. } \\
\text { no }\end{array}$ & Botanical name & Habit & Family & $\begin{array}{l}\text { Vernacular } \\
\text { name }\end{array}$ & $\begin{array}{l}\text { Common } \\
\text { name }\end{array}$ & $\begin{array}{l}\text { Plant } \\
\text { part(s) } \\
\text { uses }\end{array}$ & $\begin{array}{l}\text { Administration and mode of } \\
\text { preparation of medicines }\end{array}$ & $\begin{array}{l}\text { Medicinal } \\
\text { use (diseases) }\end{array}$ & $\begin{array}{l}\text { Name of } \\
\text { the } \\
\text { grove }\end{array}$ \\
\hline 1 & Abrus precatorius $\mathrm{L}$. & $\mathrm{C}$ & Fabaceae & Kundumani & $\begin{array}{l}\text { Coral bead } \\
\text { vine }\end{array}$ & Leaf & $\begin{array}{l}\text { Equal amount of leaf of this plant } \\
\text { along with jaggery and gingelly } \\
\text { seeds are mixed and made into a } \\
\text { paste. Lemon juice is given to the } \\
\text { girl to activate puberty on the } \\
\text { condition that on medication the } \\
\text { girl takes unripened bannana }\end{array}$ & $\begin{array}{l}\text { Attain } \\
\text { puberty }\end{array}$ & VM \\
\hline 2 & Acacia ferruginea DC. & $\mathrm{T}$ & Mimosaceae & Chimai velvel & Rusty acacia & Bark & $\begin{array}{l}\text { Bark consumed with curd to again } \\
\text { activate for poison is made into a } \\
\text { powder of bark to use to clean } \\
\text { the teeth to avoid tooth ache }\end{array}$ & $\begin{array}{l}\text { Again action } \\
\text { for poison and } \\
\text { teeth disease }\end{array}$ & VR \\
\hline 3 & Acacia caesia (L.) Willd. & $\mathrm{L}$ & Mimosaceae & Kari-indu & $\begin{array}{l}\text { Twisted } \\
\text { acacia }\end{array}$ & Leaf & $\begin{array}{l}\text { Powder of the leaf applied for lice } \\
\text { killer }\end{array}$ & Lice killer & $\mathrm{KI}$ \\
\hline 4 & Acacia nilotica (L.) Delile & $\mathrm{T}$ & Mimosaceae & Karivelam & Black babul & Bark & $\begin{array}{l}\text { Powder of bark used as mouth } \\
\text { wash to cure stomatitis and is } \\
\text { given to strengthen the teeth }\end{array}$ & Stomatitis & MD \\
\hline 5 & $\begin{array}{l}\text { Aegle marmelos (L.) } \\
\text { Corr. Serr. }\end{array}$ & $\mathrm{T}$ & Rutaceae & Vilvam & Bel & Leaf & $\begin{array}{l}\text { Extract from leaf is mixed with } \\
\text { gingelly oil and a few seeds of } \\
\text { black pepper oil heated } \\
\text { thoroughly. A spoon of this oil is } \\
\text { taken before head bath. Its regular } \\
\text { use builds up résistance to colds } \\
\text { and coughs }\end{array}$ & $\begin{array}{l}\text { Colds and } \\
\text { Coughs }\end{array}$ & VM \\
\hline 6 & $\begin{array}{l}\text { Aerva lanata (L.) Juss. ex } \\
\text { Schult. }\end{array}$ & $\mathrm{H}$ & Amaranthaceae & Sirukanpilai & $\begin{array}{l}\text { Mountain knot } \\
\text { grass }\end{array}$ & Bark & $\begin{array}{l}\text { This plant root and bark along } \\
\text { with palm sugar is mixed to make } \\
\text { a paste and taken regularly to cure } \\
\text { kidney stones. }\end{array}$ & Kidney stone & MD \\
\hline 7 & $\begin{array}{l}\text { Albizia amara (roxb.) } \\
\text { Boivin }\end{array}$ & $\mathrm{T}$ & Mimosaceae & Usil & Krishna siris & Leaf & $\begin{array}{l}\text { The extract of its leaf is used in } \\
\text { the treatment of skin disease }\end{array}$ & Skin disease & $\mathrm{DM}$ \\
\hline 8 & $\begin{array}{l}\text { Albizia lebbeck (L.) } \\
\text { Benth. }\end{array}$ & $\mathrm{T}$ & Mimosaceae & Vagai & Siris & Flower & $\begin{array}{l}\text { Paste of this flower is used } \\
\text { externally on tumor. And seeds } \\
\text { are soaked in water and used to } \\
\text { treat eye diseases }\end{array}$ & $\begin{array}{l}\text { Tumor and } \\
\text { eye diseases }\end{array}$ & VPM \\
\hline 9 & $\begin{array}{l}\text { Allophylus serratus } \\
\text { (Roxb.) kurz. }\end{array}$ & $\mathrm{S}$ & Sapindaceae & Siruvalli & & Root & $\begin{array}{l}\text { Roots in water are boiled and } \\
\text { filtered One glass is taken to cure } \\
\text { diarrhea }\end{array}$ & Diarrhea & EI \\
\hline 10 & Aloe vera (L.) Burm.f. & $\mathrm{H}$ & Asphodelaceae & Katralai & Brun plant & $\begin{array}{l}\text { Whole } \\
\text { plant }\end{array}$ & $\begin{array}{l}\text { Peels leaf bladders } 10 \mathrm{~g} \text { is taken } \\
\text { and added with lemon juice and } \\
\text { honey. This mix of juice is taken } \\
\text { daily in the morning to cure ulcer } \\
\text { and paste of aloe applied to hair to } \\
\text { remove dandruff }\end{array}$ & $\begin{array}{l}\text { Ulcer, } \\
\text { Dandruff }\end{array}$ & $\mathrm{KR}$ \\
\hline
\end{tabular}




\begin{tabular}{|c|c|c|c|c|c|c|c|c|c|}
\hline $\begin{array}{l}\text { Sl. } \\
\text { no }\end{array}$ & Botanical name & Habit & Family & $\begin{array}{l}\text { Vernacular } \\
\text { name }\end{array}$ & $\begin{array}{l}\text { Common } \\
\text { name }\end{array}$ & $\begin{array}{l}\text { Plant } \\
\text { part(s) } \\
\text { uses }\end{array}$ & $\begin{array}{l}\text { Administration and mode of } \\
\text { preparation of medicines }\end{array}$ & $\begin{array}{l}\text { Medicinal } \\
\text { use (diseases) }\end{array}$ & $\begin{array}{l}\text { Name of } \\
\text { the } \\
\text { grove }\end{array}$ \\
\hline 11 & $\begin{array}{l}\text { Andrographis paniculata } \\
\text { (Burm.f.) Nees }\end{array}$ & $\mathrm{H}$ & Acanthaceae & Nilavempu & Kariyat & $\begin{array}{l}\text { Whole } \\
\text { plant }\end{array}$ & $\begin{array}{l}\text { Dry in shade light and make into a } \\
\text { powder. It is taken daily for } \\
\text { diabetes }\end{array}$ & Diabetes & VR \\
\hline 12 & $\begin{array}{l}\text { Atalantia monophylla (L.) } \\
\text { DC. }\end{array}$ & $\mathrm{T}$ & Rutaceae & Kattu elumichai & $\begin{array}{l}\text { Indian } \\
\text { atalantia }\end{array}$ & Fruit & $\begin{array}{l}\text { The juice of this fruit is mixed } \\
\text { with salt. It is a medicinal } \\
\text { preparation for skin diseases }\end{array}$ & Skin disease & EI \\
\hline 13 & Barleria prionitis L. & $\mathrm{H}$ & Acanthaceae & Kundan & $\begin{array}{l}\text { Porcupine } \\
\text { flower }\end{array}$ & Leaf & $\begin{array}{l}\text { Leaf extract applied externally for } \\
\text { foot cracks cure }\end{array}$ & Foot crack & UI \\
\hline 14 & $\begin{array}{l}\text { Basilicum polystachyon } \\
\text { (L.) Moench }\end{array}$ & $\mathrm{H}$ & Laminaceae & Canakkirai & Musk Basil & Leaf & $\begin{array}{l}\text { Leaf grind is applied externally } \\
\text { for treating sprain and a few drops } \\
\text { of leaf infusion through the nose } \\
\text { to cure headache }\end{array}$ & $\begin{array}{l}\text { Sprain and } \\
\text { Headache }\end{array}$ & KR \\
\hline 15 & $\begin{array}{l}\text { Blepharis } \\
\quad \text { maderaspatensis }(\mathrm{L} .) \\
\quad \text { B.Heyne ex Roth }\end{array}$ & $\mathrm{H}$ & Acanthaceae & Kuraval chedi & $\begin{array}{l}\text { Creeping } \\
\text { blepharis }\end{array}$ & Root & $\begin{array}{l}\text { Root boiled in water. Extract of } \\
\text { this decoction is consumed to cure } \\
\text { syphilis }\end{array}$ & Syphilis & VR \\
\hline 16 & Boerhaavia diffusa $\mathrm{L}$. & $\mathrm{H}$ & Nyctaginaceae & Saaranathi & Wine flower & Root & $\begin{array}{l}\text { Paste of roots can be applied on } \\
\text { the oedematous swelling to cure } \\
\text { oedema }\end{array}$ & Oedema & PI \\
\hline 17 & Borassus flabellifer L. & $\mathrm{T}$ & Arecaceae & Pannaimaram & Palmyra tree & Flower & $\begin{array}{l}\text { The toddy of this tree acts as an } \\
\text { aphrodisiac If taken regularly for } \\
40 \text { days. In large doses it affects } \\
\text { the liver }\end{array}$ & Aphrodisiac & PI \\
\hline 18 & $\begin{array}{l}\text { Bulbostylis barbata } \\
\text { (Rottb.) Kunth ex C.B. } \\
\text { Clarke }\end{array}$ & $\mathrm{H}$ & Cyperaceae & mukkutikorai & & $\begin{array}{l}\text { Whole } \\
\text { plant }\end{array}$ & $\begin{array}{l}\text { Whole plant boiled in water this } \\
\text { extract is for remedy of dysentery }\end{array}$ & Dysentery & MD \\
\hline 19 & $\begin{array}{l}\text { Butea monosperma } \\
\text { (Lam.) Taub. }\end{array}$ & $\mathrm{T}$ & Fabaceae & Purasu & $\begin{array}{l}\text { Flame of the } \\
\text { forest }\end{array}$ & Seed & $\begin{array}{l}\text { The crushed seeds with lemon } \\
\text { juice applied with good results on } \\
\text { ring worms }\end{array}$ & Ring Worms & MD \\
\hline 20 & $\begin{array}{l}\text { Caesalpinia bonduc (L.) } \\
\text { Roxb. }\end{array}$ & $\mathrm{C}$ & Caesalpiniaceae & Kalichchikkai & Fever nut & Leaf & $\begin{array}{l}\text { The leaf ground with pepper to } \\
\text { make paste. This paste to use for } \\
\text { three days to cure inflamed } \\
\text { testicle. No chicken to be taken } \\
\text { during treatment. }\end{array}$ & $\begin{array}{l}\text { Inflamed } \\
\text { testicle }\end{array}$ & $\mathrm{DM}$ \\
\hline 21 & $\begin{array}{l}\text { Calotropis gigantea }(\mathrm{L} .) \\
\text { Dryand. }\end{array}$ & $S$ & Asclepiadaceae & Erukku & Crown flower & Leaf & $\begin{array}{l}\text { The leaf and castor oil made into } \\
\text { a paste and applied externally to } \\
\text { cure skin inflammation }\end{array}$ & $\begin{array}{l}\text { Skin } \\
\text { Inflammation }\end{array}$ & VR \\
\hline 22 & $\begin{array}{l}\text { Calycopteris floribunda } \mathrm{L} \\
\text { am. }\end{array}$ & $\mathrm{L}$ & Combretaceae & Pullanji valli & $\begin{array}{l}\text { Paper flower } \\
\text { climber }\end{array}$ & Leaf & $\begin{array}{l}\text { Paste of the leaf is applied to } \\
\text { bruises }\end{array}$ & Cure bruises & $\mathrm{KI}$ \\
\hline 23 & $\begin{array}{l}\text { Canthium } \\
\text { coromandelicum } \\
\text { (Burm.f.) Alston }\end{array}$ & $S$ & Rubiaceae & Sengarai & $\begin{array}{l}\text { Coramendal } \\
\text { canthium }\end{array}$ & Fruit & $\begin{array}{l}\text { The leaf and fruit are used as } \\
\text { food. Leaf and roots of this plant } \\
\text { are boiled in water. This } \\
\text { decoction cures dysentery }\end{array}$ & Dysentery & KR \\
\hline 24 & Capparis sepiaria $\mathrm{L}$. & $\mathrm{L}$ & Capparaceae & Karindu & $\begin{array}{l}\text { Wild caper } \\
\text { brush }\end{array}$ & Leaf & $\begin{array}{l}\text { Leaf added in cooking and used } \\
\text { as appetizer }\end{array}$ & Appetizer & VM \\
\hline
\end{tabular}




\begin{tabular}{|c|c|c|c|c|c|c|c|c|c|}
\hline $\begin{array}{l}\text { Sl. } \\
\text { no }\end{array}$ & Botanical name & Habit & Family & $\begin{array}{l}\text { Vernacular } \\
\text { name }\end{array}$ & $\begin{array}{l}\text { Common } \\
\text { name }\end{array}$ & $\begin{array}{l}\text { Plant } \\
\text { part(s) } \\
\text { uses }\end{array}$ & $\begin{array}{l}\text { Administration and mode of } \\
\text { preparation of medicines }\end{array}$ & $\begin{array}{l}\text { Medicinal } \\
\text { use (diseases) }\end{array}$ & $\begin{array}{l}\text { Name of } \\
\text { the } \\
\text { grove }\end{array}$ \\
\hline 25 & Capparis zeylanica L. & $\mathrm{L}$ & Capparaceae & Athondai & Indian caper & Flower & $\begin{array}{l}\text { Mixed power of the flower and } \\
\text { Arugampul root is taken daily } \\
\text { with ghee to cure haemorrhoids }\end{array}$ & Haemorrhoids & $\mathrm{KI}$ \\
\hline 26 & $\begin{array}{l}\text { Cardiospermum } \\
\text { helicacabum } \mathrm{L} .\end{array}$ & $\mathrm{C}$ & Sapindaceae & Mutakkathan & Baloon vine & Leaf & $\begin{array}{l}\text { The leaf is ground and mixed with } \\
\text { rice flour. It makes a good dosai. } \\
\text { It is used to cure rheumatism }\end{array}$ & Rheumatism & UI \\
\hline 27 & $\begin{array}{l}\text { Cascabela thevitia (L.) } \\
\text { Lipp. }\end{array}$ & $\mathrm{T}$ & Apocynaceae & Thanga arali & $\begin{array}{l}\text { Yellow } \\
\text { oleander }\end{array}$ & Seed & $\begin{array}{l}\text { Extremely poisonous but should } \\
\text { be properly used as a medicine. } \\
\text { Seeds are collected and dried in } \\
\text { sunlight and oil extracted from } \\
\text { seed. It is applied externally to } \\
\text { cure skin diseases }\end{array}$ & Skin disease & SR \\
\hline 28 & Cassia auriculata $\mathrm{L}$. & $S$ & Caesalpiniaceae & Avaram & $\begin{array}{l}\text { Tanner's } \\
\text { cassia }\end{array}$ & Flower & $\begin{array}{l}5 \text { to } 10 \text { flowers taken daily to } \\
\text { decrease sugar and make the skin } \\
\text { shine. } 100 \mathrm{ml} \text { oil are boiled to add } \\
5 \mathrm{~g} \text { of dry flower and } 5 \mathrm{~g} \text { vetiver } \\
\text { and } 5 \mathrm{~g} \text { henna. It is used to grow } \\
\text { hair to be applied for 60days }\end{array}$ & $\begin{array}{l}\text { Decrease } \\
\text { sugar, shine } \\
\text { skin, Growth } \\
\text { hair }\end{array}$ & SR \\
\hline 29 & Cassia fistula $\mathrm{L}$. & $\mathrm{T}$ & Caesalpiniaceae & Konrai & $\begin{array}{l}\text { Golden } \\
\text { shower tree }\end{array}$ & Root & $\begin{array}{l}\text { Used to treat cold and running } \\
\text { nose The smoke from the burning } \\
\text { of the root can be inhaled to cure } \\
\text { this. It encourages profuse nasal } \\
\text { discharge and helps in providing } \\
\text { relief. }\end{array}$ & Cold & $\mathrm{DM}$ \\
\hline 30 & Cassytha filiformis L. & $\mathrm{P}$ & Lauraceae & Erumai korran & Love vine & $\begin{array}{l}\text { Whole } \\
\text { plant }\end{array}$ & $\begin{array}{l}\text { The powder of whole plant is } \\
\text { mixed with dry ginger and butter } \\
\text { and is used in treating skin } \\
\text { diseases and only extract of the } \\
\text { plant is applied to inflammation } \\
\text { of the eyes }\end{array}$ & $\begin{array}{l}\text { Skin disease, } \\
\text { eyes } \\
\text { Inflammation }\end{array}$ & $\mathrm{DM}$ \\
\hline 31 & $\begin{array}{l}\text { Catharanthus roseus (L.) } \\
\text { G.Don }\end{array}$ & $\mathrm{H}$ & Apocynaceae & Sudukattu malli & Vinca & $\begin{array}{l}\text { Whole } \\
\text { plant }\end{array}$ & $\begin{array}{l}\text { Whole plant made into a powder. } \\
\text { It is also used to prevent cancer. } \\
\text { And it is made into a powder by } \\
\text { adding water to make paste. The } \\
\text { paste is applied to the nervous } \\
\text { disorders and to cure sprains and } \\
\text { inflammation of skin }\end{array}$ & $\begin{array}{l}\text { Nerous } \\
\text { disorder, } \\
\text { sprain and } \\
\text { Inflammation } \\
\text { skin }\end{array}$ & VR \\
\hline 32 & $\begin{array}{l}\text { Catunaregam spinosa } \\
\text { (Thunb.) Tirven. }\end{array}$ & $S$ & Rubiaceae & Madkarai & $\begin{array}{l}\text { Mountain } \\
\text { pomegranate }\end{array}$ & Bark & $\begin{array}{l}\text { Paste of bark externally applied to } \\
\text { relieve pain of bruises and cure } \\
\text { bone-ache }\end{array}$ & $\begin{array}{l}\text { Relieve born- } \\
\text { aches }\end{array}$ & KR \\
\hline 33 & $\begin{array}{l}\text { Chloroxylon swietenia } \\
\text { DC. }\end{array}$ & $\mathrm{T}$ & Rutaceae & Mammarai & $\begin{array}{l}\text { Ceylon } \\
\text { satinwood }\end{array}$ & Leaf & $\begin{array}{l}\text { Leaf paste is used as a first aid to } \\
\text { treat insect bites and remove } \\
\text { poison from the body by insect } \\
\text { bites }\end{array}$ & $\begin{array}{l}\text { Remove } \\
\text { poison }\end{array}$ & PI \\
\hline
\end{tabular}




\begin{tabular}{|c|c|c|c|c|c|c|c|c|c|}
\hline $\begin{array}{l}\text { Sl. } \\
\text { no }\end{array}$ & Botanical name & Habit & Family & $\begin{array}{l}\text { Vernacular } \\
\text { name }\end{array}$ & $\begin{array}{l}\text { Common } \\
\text { name }\end{array}$ & $\begin{array}{l}\text { Plant } \\
\text { part(s) } \\
\text { uses }\end{array}$ & $\begin{array}{l}\text { Administration and mode of } \\
\text { preparation of medicines }\end{array}$ & $\begin{array}{l}\text { Medicinal } \\
\text { use (diseases) }\end{array}$ & $\begin{array}{l}\text { Name of } \\
\text { the } \\
\text { grove }\end{array}$ \\
\hline 34 & Cissus vitiginea $\mathrm{L}$. & $\mathrm{L}$ & Vitaceae & Cempirantai & $\begin{array}{l}\text { South indain } \\
\text { treebine }\end{array}$ & Leaf & $\begin{array}{l}\text { Juice of leaf added to pepper. } \\
5 \mathrm{ml} \text { of the decoction should be } \\
\text { taken for relief of gastric problem }\end{array}$ & $\begin{array}{l}\text { Gastric } \\
\text { problem }\end{array}$ & EI \\
\hline 35 & Cissus quadrangularis $\mathrm{L}$. & $\mathrm{L}$ & Vitaceae & Perandai & $\begin{array}{l}\text { Divil's } \\
\text { bachbone }\end{array}$ & $\begin{array}{l}\text { Whole } \\
\text { plant }\end{array}$ & $\begin{array}{l}\text { Made into pickles to be taken } \\
\text { daily as appetizer }\end{array}$ & Appetizer & SR \\
\hline 36 & Cleome viscosa $\mathrm{L}$. & $\mathrm{H}$ & Capparaceae & Naikaduku & $\begin{array}{l}\text { Yellow spider } \\
\text { flower }\end{array}$ & Leaf & $\begin{array}{l}\text { The paste of the leaf is mixed } \\
\text { with lemon to be applied } \\
\text { externally to cure headache. } \\
\text { Flower juice is mixed with breast } \\
\text { milk and given to the child to } \\
\text { cure indigestion problem }\end{array}$ & $\begin{array}{l}\text { Headache and } \\
\text { Indigestion } \\
\text { problem }\end{array}$ & SR \\
\hline 37 & $\begin{array}{l}\text { Coccinia grandis }(\mathrm{L} .) \\
\text { Voigt }\end{array}$ & $\mathrm{L}$ & Cucurbitaceae & Kovakkai & Ivy gourd & Leaf & $\begin{array}{l}\text { Leaf juice taken in the morning } \\
\text { and evening regularly } 25 \mathrm{ml} \text {. This } \\
\text { is to cure dysentery. This juice } \\
\text { and equal quantity of oil with rice } \\
\text { boiling extract is used to cure } \\
\text { gonorrhoea }\end{array}$ & $\begin{array}{l}\text { Dysentery } \\
\text { and } \\
\text { Gonorrhoea }\end{array}$ & EI \\
\hline 38 & $\begin{array}{l}\text { Combretum albidum } \mathrm{G} . \\
\text { Don. }\end{array}$ & $\mathrm{L}$ & Fabaceae & Odaikodi & Piluki & Fruit & $\begin{array}{l}\text { The juice extract from fruit filter } \\
\text { and mixed with pepper powder is } \\
\text { consumed to cure dysentery. } \\
\text { Decoction of bark is the best } \\
\text { remedy for jaundice }\end{array}$ & $\begin{array}{l}\text { Dysentery } \\
\text { and Jaundice }\end{array}$ & MD \\
\hline 39 & Commelina benghalensis $\mathrm{L}$. & $\mathrm{H}$ & $\begin{array}{l}\text { Commelinaceae } \\
\text { Mirb. }\end{array}$ & Kanangolai & $\begin{array}{l}\text { Bengal day } \\
\text { flower }\end{array}$ & $\begin{array}{l}\text { Whole } \\
\text { plant }\end{array}$ & $\begin{array}{l}\text { The whole dried plant is made } \\
\text { into a powder and mixed with hot } \\
\text { water to cure menstrual disorder }\end{array}$ & $\begin{array}{l}\text { Menstrual } \\
\text { disorder }\end{array}$ & VPM \\
\hline 40 & $\begin{array}{l}\text { Commiphora caudata } \\
\text { (Wight \& Arn.) Engl. }\end{array}$ & $\mathrm{T}$ & Burseraceae & Mailama & Hill mango & Seed & $\begin{array}{l}\text { Powder of the seed is infused with } \\
\text { cow's milk to stop stomach pain }\end{array}$ & Stomach ache & $\mathrm{KI}$ \\
\hline 41 & Cordia monoica Roxb. & $\mathrm{T}$ & Boraginaceae & Virimaram & Snot berry & Leaf & $\begin{array}{l}\text { Leaf used for eye disorder and } \\
\text { paste of leaf applied externally to } \\
\text { cure inflammations }\end{array}$ & $\begin{array}{l}\text { Eye disorder } \\
\text { and } \\
\text { inflammations }\end{array}$ & $\mathrm{KI}$ \\
\hline 42 & $\begin{array}{l}\text { Crataeva manga (Lour.) } \\
\text { DC. }\end{array}$ & $\mathrm{T}$ & Capparaceae & Maralingam & $\begin{array}{l}\text { Three leaved } \\
\text { caper }\end{array}$ & Root & $\begin{array}{l}\text { The ash of root of this plant } 5 \mathrm{gm} \\
\text { and equal quantity of root of the } \\
\text { birdsville indigo plant, fragrant } \\
\text { swamp mallow, and mountain } \\
\text { knot grass are added with water } \\
\text { and made into a paste by boiling } \\
\text { it. It is also used to cure urinary } \\
\text { stone }\end{array}$ & Urinary stone & VPM \\
\hline 43 & $\begin{array}{l}\text { Croton bonplandianus } \\
\text { Baill. }\end{array}$ & $\mathrm{H}$ & Euphorbiaceae & Reilpoondu & Ban tulsi & Leaf & $\begin{array}{l}\text { This plant remedy is for } \\
\text { controlling high blood pressure } \\
\text { and paste of leaf to cure skin } \\
\text { diseases }\end{array}$ & $\begin{array}{l}\text { Blood } \\
\text { pressure and } \\
\text { Skin disease }\end{array}$ & EI \\
\hline 44 & Datura metel L. & $\mathrm{H}$ & Solanaceae & Oomathai & $\begin{array}{l}\text { Devil's } \\
\text { trumpet }\end{array}$ & Flower & $\begin{array}{l}\text { The leaf and flowers are dried in } \\
\text { sunlight. The smoke can be } \\
\text { inhaled to cure asthma }\end{array}$ & Asthma & VM \\
\hline
\end{tabular}




\begin{tabular}{|c|c|c|c|c|c|c|c|c|c|}
\hline $\begin{array}{l}\text { Sl. } \\
\text { no }\end{array}$ & Botanical name & Habit & Family & $\begin{array}{l}\text { Vernacular } \\
\text { name }\end{array}$ & $\begin{array}{l}\text { Common } \\
\text { name }\end{array}$ & $\begin{array}{l}\text { Plant } \\
\text { part(s) } \\
\text { uses }\end{array}$ & $\begin{array}{l}\text { Administration and mode of } \\
\text { preparation of medicines }\end{array}$ & $\begin{array}{l}\text { Medicinal } \\
\text { use (diseases) }\end{array}$ & $\begin{array}{l}\text { Name of } \\
\text { the } \\
\text { grove }\end{array}$ \\
\hline 45 & $\begin{array}{l}\text { Delonix elata }(\mathrm{L} .) \\
\quad \text { Gamble }\end{array}$ & $\mathrm{T}$ & Caesalpiniaceae & Perungonrai & $\begin{array}{l}\text { White } \\
\text { gulmohar }\end{array}$ & Leaf & $\begin{array}{l}\text { The crushed leaf is boiled in } \\
\text { water and is used externally to } \\
\text { reduce the pain of joints }\end{array}$ & Joint pain & SR \\
\hline 46 & $\begin{array}{l}\text { Dendrophthoe falcata } \\
\text { (L.f.) Ettingsh. }\end{array}$ & $P$ & Loranthaceae & Pulluruvi & $\begin{array}{l}\text { Honey suckle } \\
\text { mistle }\end{array}$ & $\begin{array}{l}\text { Whole } \\
\text { plant }\end{array}$ & $\begin{array}{l}\text { This is used as an antidote for } \\
\text { poison of Strychnos nuxvomica }\end{array}$ & $\begin{array}{l}\text { Antidote for } \\
\text { nux vomica }\end{array}$ & UI \\
\hline 47 & $\begin{array}{l}\text { Derris ovalifolia (Wight } \\
\quad \text { \& Arn.) Benth. }\end{array}$ & $\mathrm{L}$ & Fabaceae & Pungam & Kanara derris & Bark & $\begin{array}{l}\text { Paste of the bark is applied for } \\
\text { treatment of insect bites }\end{array}$ & Insect bites & MR \\
\hline 48 & $\begin{array}{l}\text { Dichrostachys cinerea } \\
\text { (L.) Wight \& Arn. }\end{array}$ & $\mathrm{T}$ & Mimosaceae & Veduttalam & Sickle brush & Bark & $\begin{array}{l}\text { Powder of the root along with } \\
\text { milk is taken for } 48 \text { days to cure } \\
\text { elephantiasis }\end{array}$ & Elephantiasis & $\mathrm{DM}$ \\
\hline 49 & $\begin{array}{l}\text { Dioscorea oppositifolia } \mathrm{L} \\
\quad .\end{array}$ & $\mathrm{L}$ & Dioscoreaceae & Vettilaivalli & Chinese yam & Tuber & $\begin{array}{l}\text { Boiled tubers are eaten especially } \\
\text { for pregnant women to get } \\
\text { strength. It is mostly given to } \\
\text { women after childbirth }\end{array}$ & $\begin{array}{l}\text { Body strength } \\
\text { for women }\end{array}$ & PI \\
\hline 50 & Euphorbia hirta L. & $\mathrm{H}$ & Euphorbiaceae & Amman pacharisi & Asthma weed & Latex & $\begin{array}{l}\text { Latex directly applied on external } \\
\text { skin of pimples. It cures pimples } \\
\text { and cracked lips. }\end{array}$ & Pimples & VPM \\
\hline 51 & Evolvulus alsinoides L. & $\mathrm{H}$ & Convolvulaceae & Vishnukarathai & $\begin{array}{l}\text { Darf morning } \\
\text { glory }\end{array}$ & Leaf & $\begin{array}{l}\text { The leaf dried in sun light and } \\
\text { made into powder. The powder is } \\
\text { mixed with coconut water and } \\
\text { taken daily in the morning to } \\
\text { improve fertility }\end{array}$ & $\begin{array}{l}\text { Improve } \\
\text { fertility }\end{array}$ & SR \\
\hline 52 & Ficus amplissima J. E. & $\mathrm{T}$ & Moraceae & Kal athi & & Latex & $\begin{array}{l}\text { For the fracture of bones, the latex } \\
\text { and bark is tied around the broken } \\
\text { bone which will be cured. }\end{array}$ & Bone Fracture & MR \\
\hline 53 & Ficus glomerata Rox. & $\mathrm{T}$ & Moraceae & Atthi & Cluster fig & Fruit & $\begin{array}{l}\text { The fruit ground with milk and } \\
\text { added honey. taken in the } \\
\text { morning on an empty stomach for } \\
18 \text { days increases the } \\
\text { haemoglobin content in the blood }\end{array}$ & $\begin{array}{l}\text { Increase } \\
\text { Haemoglobin }\end{array}$ & UI \\
\hline 54 & Ficus benghalensis L. & $\mathrm{T}$ & Moraceae & Aal & Banyan & Root & $\begin{array}{l}5 \mathrm{~g} \text { adventives root and one or two } \\
\text { peppers added and ground and } \\
\text { mixed with milk and taken for } 7 \\
\text { days. It improves lactation of } \\
\text { expectant mothers }\end{array}$ & $\begin{array}{l}\text { Increase } \\
\text { Lactation of } \\
\text { expectant } \\
\text { mother }\end{array}$ & MD \\
\hline 55 & Gloriosa superba $\mathrm{L}$. & $\mathrm{C}$ & Liliaceae Juss. & Senkanthal & Glory lily & Tuber & $\begin{array}{l}\text { The tuber is made into a fine paste } \\
\text { with milk and applied externally } \\
\text { to cure skin diseases }\end{array}$ & Skin disease & $\mathrm{KI}$ \\
\hline 56 & Gmelina asiatica $\mathrm{L}$. & S & Verbenaceae & Kumil & $\begin{array}{l}\text { Asian bush } \\
\text { beech }\end{array}$ & Fruit & $\begin{array}{l}\text { The fruit is crushed and applied } \\
\text { to scalp to cure dandruff and cool } \\
\text { the body }\end{array}$ & $\begin{array}{l}\text { Dandruff and } \\
\text { Cool body }\end{array}$ & UI \\
\hline 57 & Grewia orientalis L. & $\mathrm{L}$ & Tiliaceae & Kodividalai & & Root & $\begin{array}{l}\text { Root extract as infusion to } \\
\text { develop sterility in women }\end{array}$ & $\begin{array}{l}\text { Sterility in } \\
\text { women }\end{array}$ & EI \\
\hline 58 & $\begin{array}{l}\text { Gyrocarpus americanus } \\
\text { Jacq. }\end{array}$ & $\mathrm{T}$ & Hernandiaceae & Kadavai & $\begin{array}{l}\text { Helicopter } \\
\text { tree }\end{array}$ & Bark & $\begin{array}{l}\text { Paste of bark externally applied } \\
\text { on forehead to cure colds }\end{array}$ & Cold & UI \\
\hline
\end{tabular}




\begin{tabular}{|c|c|c|c|c|c|c|c|c|c|}
\hline $\begin{array}{l}\text { Sl. } \\
\text { no }\end{array}$ & Botanical name & Habit & Family & $\begin{array}{l}\text { Vernacular } \\
\text { name }\end{array}$ & $\begin{array}{l}\text { Common } \\
\text { name }\end{array}$ & $\begin{array}{l}\text { Plant } \\
\text { part(s) } \\
\text { uses }\end{array}$ & $\begin{array}{l}\text { Administration and mode of } \\
\text { preparation of medicines }\end{array}$ & $\begin{array}{l}\text { Medicinal } \\
\text { use (diseases) }\end{array}$ & $\begin{array}{l}\text { Name of } \\
\text { the } \\
\text { grove }\end{array}$ \\
\hline 59 & $\begin{array}{l}\text { Hemidesmus indicus (L.) } \\
\quad \text { R. Br. ex Schult. }\end{array}$ & $\mathrm{H}$ & Asclepiadaceae & Nannari & Sarsaparilla & Root & $\begin{array}{l}\text { The roots ground with water and } \\
\text { mixed with pepper is useful in } \\
\text { stomach ache cases }\end{array}$ & Stomach ache & KR \\
\hline 60 & $\begin{array}{l}\text { Holoptelea integrifolia } \\
\quad \text { (Roxb.) Planch. }\end{array}$ & $\mathrm{T}$ & Ulmaceae & Aya & Indian elm & Bark & $\begin{array}{l}\text { Powder of the bark mixed with } \\
\text { water made into a paste and } \\
\text { applied to cure skin diseases }\end{array}$ & Skin diseases & SR \\
\hline 61 & Hugonia mystax L. & $\mathrm{L}$ & Linaceae & Mothirakanni & Climbing flax & Root & $\begin{array}{l}\text { Root powder applied externally } \\
\text { on swelling skin to cure } \\
\text { inflammation }\end{array}$ & Inflammation & $\mathrm{DM}$ \\
\hline 62 & $\begin{array}{l}\text { Hybanthus enneaspermus } \\
\text { (L.) F.v. Muell. }\end{array}$ & $\mathrm{H}$ & Violaceae Batsch & Orithal thamarai & Spade flower & $\begin{array}{l}\text { Whole } \\
\text { plant }\end{array}$ & $\begin{array}{l}\text { Whole plant dried in the shade } \\
\text { light after making into a fine } \\
\text { powder. The powder is then } \\
\text { mixed with cow milk and honey } \\
\text { and consumed to improve sexual } \\
\text { activities }\end{array}$ & $\begin{array}{l}\text { Sexual } \\
\text { activities }\end{array}$ & VM \\
\hline 63 & $\begin{array}{l}\text { Ipomea staphylina Roem. } \\
\text { \& Schult. }\end{array}$ & $\mathrm{L}$ & Convolvulaceae & Onakodi & & Leaf & $\begin{array}{l}\text { Leaf boiled in water. The leaf is } \\
\text { applied on dropsy swelling area } \\
\text { on legs and hand to reduce } \\
\text { swelling }\end{array}$ & $\begin{array}{l}\text { Dropsy } \\
\text { swelling }\end{array}$ & $\mathrm{DM}$ \\
\hline 64 & $\begin{array}{l}\text { Jasminum angustifolium } \\
\text { (L.) Willd. }\end{array}$ & $\mathrm{L}$ & Oleaceae & Kattu malligai & Wild jasmine & Flower & $\begin{array}{l}\text { Paste of the flower externally } \\
\text { applied on breast after child birth } \\
\text { to increase mother's milk and } \\
\text { reduce breast pain }\end{array}$ & $\begin{array}{l}\text { Increase } \\
\text { mother's milk } \\
\text { and breast } \\
\text { pain }\end{array}$ & SR \\
\hline 65 & $\begin{array}{l}\text { Lannea coromandelica } \\
\text { (Houtt.) Merr. }\end{array}$ & $\mathrm{T}$ & Anacardiaceae & Uthiyamaram & Indain ash tree & Leaf & $\begin{array}{l}\text { Boiled leaf are applied on bruises } \\
\text {, swellings, and is used to cure } \\
\text { filariasis }\end{array}$ & Filariasis & VPM \\
\hline 66 & $\begin{array}{l}\text { Lepisanthes tetraphylla } \\
\text { (Vahl) Radlk. }\end{array}$ & $\mathrm{T}$ & Sapindaceae & Karadipongan & Kurpa & Leaf & $\begin{array}{l}\text { Dried leaf is burned to ash and is } \\
\text { mixed with castor oil to externally } \\
\text { apply to cure filariasis }\end{array}$ & Filariasis & VPM \\
\hline 67 & Limonia acidissima $\mathrm{L}$. & $\mathrm{T}$ & Rutaceae & Vilampalam & Wood apple & Fruit & $\begin{array}{l}\text { The ripe fruit dried in shade and } \\
\text { ground into a powder to take daily } \\
\text { one spoon with water to cure } \\
\text { digestive disorders and to prevent } \\
\text { cancer of the breast }\end{array}$ & $\begin{array}{l}\text { Digestive } \\
\text { disorders, } \\
\text { Breast cancer }\end{array}$ & VPM \\
\hline 68 & $\begin{array}{l}\text { Maytenus emarginata } \\
\text { (Ruiz \& Pav.) Loes. }\end{array}$ & $\mathrm{S}$ & Celastraceae & Kattangi & $\begin{array}{l}\text { Red spike } \\
\text { thorn }\end{array}$ & Bark & $\begin{array}{l}\text { The bark is made into a fine paste } \\
\text { with coconut oil and applied on } \\
\text { scalp to kill lice and remove } \\
\text { dandruff }\end{array}$ & $\begin{array}{l}\text { Kill lice and } \\
\text { dandruff }\end{array}$ & VM \\
\hline 69 & $\begin{array}{l}\text { Mitragyna parvifolia } \\
\text { (Roxb.) Korth. }\end{array}$ & $\mathrm{T}$ & Rubiaceae & Neer Kadambu & Kaim & Bark & $\begin{array}{l}\text { The bark is boiled in water to be } \\
\text { taken internally to cure fever }\end{array}$ & Fever & EI \\
\hline 70 & Moringa oleifera Lam. & $\mathrm{T}$ & Moringaceae & Murungai & Drumstrick & Flower & $\begin{array}{l}\text { The flowers of the nochi (Vitex) } \\
\text { and Drumstrick flower is crushed } \\
\text { and added to milk. It is taken at } \\
\text { night to improve fertility. }\end{array}$ & $\begin{array}{l}\text { Improve } \\
\text { fertility }\end{array}$ & KI \\
\hline
\end{tabular}




\begin{tabular}{|c|c|c|c|c|c|c|c|c|c|}
\hline $\begin{array}{l}\text { Sl. } \\
\text { no }\end{array}$ & Botanical name & Habit & Family & $\begin{array}{l}\text { Vernacular } \\
\text { name }\end{array}$ & $\begin{array}{l}\text { Common } \\
\text { name }\end{array}$ & $\begin{array}{l}\text { Plant } \\
\text { part(s) } \\
\text { uses }\end{array}$ & $\begin{array}{l}\text { Administration and mode of } \\
\text { preparation of medicines }\end{array}$ & $\begin{array}{l}\text { Medicinal } \\
\text { use (diseases) }\end{array}$ & $\begin{array}{l}\text { Name of } \\
\text { the } \\
\text { grove }\end{array}$ \\
\hline 71 & Nerium oleander L. & $\mathrm{T}$ & Apocynaceae & Arali & Oleander & Flower & $\begin{array}{l}\text { Paste made from the flower is } \\
\text { crushed and boiled in castor oil. } \\
\text { Paste is then externally applied on } \\
\text { swelling to cure inflammation }\end{array}$ & Inflammation & $\mathrm{DM}$ \\
\hline 72 & Ocimum cannum Sims L. & $\mathrm{H}$ & Laminaceae & Nai thulasi & Wild basil & Leaf & $\begin{array}{l}\text { Leaf boiled in water after } \\
\text { filtering. The extract with jaggery } \\
\text { is consumed to cure coughs }\end{array}$ & Coughs & KR \\
\hline 73 & $\begin{array}{l}\text { Pamburus missionis } \\
\text { (Wall. ex Wight) } \\
\text { Swingle }\end{array}$ & $\mathrm{T}$ & Rutaceae & Kattu alumichai & & Leaf & $\begin{array}{l}\text { Leaf paste is applied on fractured } \\
\text { area or wound swelling to cure } \\
\text { the same. }\end{array}$ & Fractures & UI \\
\hline 74 & $\begin{array}{l}\text { Pavonia zeylanica }(\mathrm{L} .) \\
\text { Cav. }\end{array}$ & $\mathrm{H}$ & Malvaceae & Savagan & $\begin{array}{l}\text { Ceylon } \\
\text { swamp } \\
\text { mallow }\end{array}$ & $\begin{array}{l}\text { Whole } \\
\text { plant }\end{array}$ & $\begin{array}{l}\text { Whole plant used as pain reliever } \\
\text { of rheumatism }\end{array}$ & Rheumatism & VM \\
\hline 75 & $\begin{array}{l}\text { Phyllanthus amarus } \\
\text { Schumach. \& Thonn. }\end{array}$ & $\mathrm{H}$ & Euphorbiaceae & Keelaneli & Carry me seed & Root & $\begin{array}{l}\text { Root ground and made into a } \\
\text { paste. The paste is then boiled in } \\
\text { coconut oil after filtering then } \\
\text { apply on scalp for growing hair } \\
\text { and curing baldness }\end{array}$ & $\begin{array}{l}\text { Disappear } \\
\text { baldness }\end{array}$ & VM \\
\hline 76 & Pisonia aculeata $\mathrm{L}$. & $\mathrm{L}$ & Nyctaginaceae & $\begin{array}{l}\text { Kodi } \\
\text { kuttippadatthi, } \\
\text { Marukalli, } \\
\text { Selamaranjaan }\end{array}$ & Lettuce tree & Bark & $\begin{array}{l}\text { Paste of bark externally applied to } \\
\text { cure rheumatism }\end{array}$ & Rheumatism & $\mathrm{KI}$ \\
\hline 77 & $\begin{array}{l}\text { Pleiospermium alatum } \\
\text { (Wight \& Arn.) } \\
\text { Swingle }\end{array}$ & $\mathrm{T}$ & Rutaceae & $\begin{array}{l}\text { Malai narathai; } \\
\text { Kaattu kichili }\end{array}$ & & Leaf & $\begin{array}{l}\text { Leaf paste used as wound healing } \\
\text { property }\end{array}$ & $\begin{array}{l}\text { Wound } \\
\text { healing }\end{array}$ & VM \\
\hline 78 & $\begin{array}{l}\text { Pongamia pinnata }(\mathrm{L} .) \\
\text { Pier. }\end{array}$ & $\mathrm{T}$ & Fabaceae & Pungai & Pongam tree & Leaf & $\begin{array}{l}\text { Leaf juice infusion cures } \\
\text { rheumatism }\end{array}$ & Rheumatism & MR \\
\hline 79 & $\begin{array}{l}\text { Reissantia indica (Willd.) } \\
\text { N. Hallé }\end{array}$ & $\mathrm{L}$ & Celastraceae & Odangod & $\begin{array}{l}\text { Mopane } \\
\text { paddle-pod }\end{array}$ & Root & $\begin{array}{l}\text { Root powder applied on sore } \\
\text { wound }\end{array}$ & $\begin{array}{l}\text { Sore and } \\
\text { wound }\end{array}$ & $\mathrm{KI}$ \\
\hline 80 & $\begin{array}{l}\text { Rivea hypocrateriformis } \\
\text { Choisy }\end{array}$ & $\mathrm{L}$ & Convolvulaceae & $\begin{array}{l}\text { Musuttai kodi, } \\
\text { Budthi kirai }\end{array}$ & $\begin{array}{l}\text { Midna pore } \\
\text { creeper }\end{array}$ & Leaf & $\begin{array}{l}\text { The leaf is used by local medicine } \\
\text { man. The juice of leaf is given to } \\
\text { women after childbirth. It is for } \\
\text { control of hemorrhage }\end{array}$ & $\begin{array}{l}\text { Hemorrhages } \\
\text { disease }\end{array}$ & VM \\
\hline 81 & Salvadora persica $\mathrm{L}$. & $\mathrm{T}$ & Salvadoraceae & Uka & Salt brush & Leaf & $\begin{array}{l}\text { Decoction of leaf used as mouth } \\
\text { wash to cure mouth ulcer }\end{array}$ & Mouth ulcer & EI \\
\hline 82 & $\begin{array}{l}\text { Sansevieria roxburghiana } \\
\text { Schult. \& Schult. f. }\end{array}$ & $\mathrm{H}$ & Asparagaceae & Marul & & Leaf & $\begin{array}{l}\text { Castor oil applied on the plant } \\
\text { leaf and burned lightly after being } \\
\text { crushed to get extract. The extract } \\
\text { cures earache }\end{array}$ & Earache & EI \\
\hline 83 & $\begin{array}{l}\text { Scutia myrtina (Burm. f.) } \\
\quad \text { Kurz }\end{array}$ & $\mathrm{L}$ & Rhamnaceae & Tuvadi & Cat thorn & Fruit & $\begin{array}{l}\text { The edible fruit is used as } \\
\text { astringent }\end{array}$ & Astringent & $\mathrm{KI}$ \\
\hline 84 & Sida acuta Burm.f. & $\mathrm{H}$ & Malvaceae & Palambasi & $\begin{array}{l}\text { Common wire } \\
\text { weed }\end{array}$ & Flower & $\begin{array}{l}\text { Dried flower ground and boiled in } \\
\text { water. This decoction is used to } \\
\text { wash teeth to get strong and get } \\
\text { relief from tooth pain }\end{array}$ & Teeth pain & PI \\
\hline
\end{tabular}




\begin{tabular}{|c|c|c|c|c|c|c|c|c|c|}
\hline $\begin{array}{l}\text { Sl. } \\
\text { no }\end{array}$ & Botanical name & Habit & Family & $\begin{array}{l}\text { Vernacular } \\
\text { name }\end{array}$ & $\begin{array}{l}\text { Common } \\
\text { name }\end{array}$ & $\begin{array}{l}\text { Plant } \\
\text { part(s) } \\
\text { uses }\end{array}$ & $\begin{array}{l}\text { Administration and mode of } \\
\text { preparation of medicines }\end{array}$ & $\begin{array}{l}\text { Medicinal } \\
\text { use (diseases) }\end{array}$ & $\begin{array}{l}\text { Name of } \\
\text { the } \\
\text { grove }\end{array}$ \\
\hline 85 & Sida cordifolia $\mathrm{L}$. & $\mathrm{H}$ & Malvaceae & $\begin{array}{l}\text { Arivalmanai } \\
\text { poondu }\end{array}$ & Heart leaf sida & $\begin{array}{l}\text { Whole } \\
\text { plant }\end{array}$ & $\begin{array}{l}\text { Whole plant ground into an } \\
\text { extract. Then extract filter is used } \\
\text { as antiseptic to wash bruised area } \\
\text { to cure bruises quickly }\end{array}$ & $\begin{array}{l}\text { Antiseptic } \\
\text { and bruises }\end{array}$ & PI \\
\hline 86 & $\begin{array}{l}\text { Syzygium cumini (L.) } \\
\quad \text { Skeels }\end{array}$ & $\mathrm{T}$ & Myrtaceae & Naval & Java plum & Seed & $\begin{array}{l}\text { Seed made into a fine powder and } \\
\text { taken with water daily to control } \\
\text { diabetics }\end{array}$ & Diabetices & MR \\
\hline 87 & Tamarindus indica $\mathrm{L}$. & $\mathrm{T}$ & Caesalpiniaceae & Puli & Tamarind & Seed & $\begin{array}{l}\text { Seeds ground to make powder } \\
\text { after few seeds fried and mixed } \\
\text { with Cumin and sugar to make } \\
\text { juice. It is taken for } 3 \text { days daily } \\
\text { twice for dysentery }\end{array}$ & Dysentery & VPM \\
\hline 88 & $\begin{array}{l}\text { Thespesia populnea }(\mathrm{L} .) \\
\text { Sol. ex Corrêa }\end{array}$ & $\mathrm{T}$ & Malvaceae & Puvarasu & $\begin{array}{l}\text { Indian tulip } \\
\text { tree }\end{array}$ & Bark & $\begin{array}{l}\text { Bark extract with jaggery made } \\
\text { into a juice and taken orally to } \\
\text { cure leucoderma }\end{array}$ & Leucoderma & $\mathrm{DM}$ \\
\hline 89 & $\begin{array}{l}\text { Tinospora cordifolia } \\
\text { (Willd.) Hook. f. \& } \\
\text { Thomson }\end{array}$ & $\mathrm{L}$ & Menispermaceae & Kunali & Gulbel & Leaf & $\begin{array}{l}\text { The juice from leaf is added to } \\
\text { honey and taken on empty } \\
\text { stomach to cure gastric problem }\end{array}$ & $\begin{array}{l}\text { Gastric } \\
\text { problems }\end{array}$ & $\mathrm{KI}$ \\
\hline 90 & Tridax procumbens L. & $\mathrm{H}$ & Asteraceae & Thatha poo & Tridax daisy & Leaf & $\begin{array}{l}\text { The leaf is directly applied on } \\
\text { blood from wound and some } \\
\text { insect bites to cure poison }\end{array}$ & $\begin{array}{l}\text { Stop bleeding } \\
\text { and Remove } \\
\text { poison }\end{array}$ & UI \\
\hline 91 & $\begin{array}{l}\text { Ventilago maderaspatana } \\
\text { Gaertn. }\end{array}$ & $\mathrm{L}$ & Rhamnaceae & Surapattai kottai & Red creeper & Bark & $\begin{array}{l}\text { Powder of bark infusion is taken } \\
\text { to get energy }\end{array}$ & Energy drink & MR \\
\hline 92 & Vitex negundo L. & $\mathrm{T}$ & Laminaceae & Nochi & Chaste tree & Flower & $\begin{array}{l}5 \mathrm{~g} \text { flower with } 5 \mathrm{~g} \text { drumstick is } \\
\text { crushed and mixed with milk and } \\
\text { consumed for } 7 \text { days in night. It is } \\
\text { to improve sexual activities and } \\
\text { cure liver disorders }\end{array}$ & $\begin{array}{l}\text { Improve } \\
\text { fertility }\end{array}$ & $\mathrm{KR}$ \\
\hline 93 & Ziziphus mauritiana Lam. & $\mathrm{T}$ & Rhamnaceae & Elanthai & Indain jujube & Fruit & $\begin{array}{l}\text { Dry fruit are boiled in a litre of } \\
\text { water and added with sugar and } \\
\text { honey. It is given daily at night } \\
\text { before retiring. It activates the } \\
\text { brain }\end{array}$ & $\begin{array}{l}\text { Functioning } \\
\text { of brain }\end{array}$ & $\mathrm{KR}$ \\
\hline 94 & $\begin{array}{l}\text { Ziziphus oenoplia (L.) } \\
\quad \text { Mill. }\end{array}$ & $\mathrm{L}$ & Rhamnaceae & Surai elanthai & Jackal jujube & Leaf & $\begin{array}{l}\text { Leaf paste is applied to forehead } \\
\text { for activating the brain and curing } \\
\text { brain nervous disorder }\end{array}$ & Madness & VR \\
\hline
\end{tabular}




\section{Conclusion}

The collected data was documented on the basis of the plant scientific name, vernacular name, family, habitat, plant part usage and ability to cure the disease. A total of 94 species belonging to 84 genera and 47 families were enumerated in the twelve sacred grove sites studied. Plants such as Abrus precatorius L., Acacia caesia (L.) Willd., Albizia lebbeck (L.) Benth., Andrographis paniculata (Burm.f.) Nees, Blepharis maderaspatensis (L.) B.Heyne ex Roth, Capparis zeylanica L., Hybanthus enneaspermus (L.) F.v. Muell., Lepisanthes tetraphylla (Vahl) Radlk. and Ziziphus mauritiana Lam. These plants are used for attaining puberty, killing of lice, tumor and eye diseases, diabetes, syphilis, haemorrhoids, sexual activities, filariasis, functioning of the brain, etc.

Hence, it has been established that herbal based medicine is an effective cure for many diseases. Every house should maintain a small herbal garden were plants that meet the needs of primary health care are grown. Thus, the medicinally important plants will be conserved as well as the indigenous knowledge of traditional medicine will be utilized by the present as well as future generations.

\section{Conflict of interest statement}

There is no conflict of interest.

\section{Acknowledgement}

I wish to express my gratitude to Dr. Nanditha Krishna, Honorary Director of C.P.R. Environmental Education Centre for her constant encouragement and to deepen my interest about the Plant diversity and nature conservation. I am also thankful to M. Amirthalingam and N. Onkar for their valuable comments on this paper.

\section{References}

Amirthalingam, M., 2012. Sacred groves of Tamil Nadu and their Management. Department of Forest Extension Centre, Forest Department, Government of Tamil Nadu.

Balakrishnan, N.P., Chakrabarty, T., 2007. The Family Euphorbiaceae in India - A Synopsis of its Profile, Taxonomy and Bibliography. Bishen Singh Mahendra Pal Singh, Dehra Dun. 500p.

Gamble, J.S., 1915-1936. Flora of the Presidency of Madras. 11 Parts (Parts $1-7$ by Gamble and $8-11$ by C.E.C. Fischer), London. Repr. Edn. 1957. Botanical Survey of India, Calcutta. 2017p.

Henry, A.N., Chithra, V., Balakrishnan, N.P., 1989. Flora of Tamil Nadu, India. Series 1: Analysis. Vol. 3. Botanical Survey of India, Coimbatore. 173p.

Henry, A.N., Kumari, G.R., Chithra, V., 1987. Flora of Tamil Nadu, India. Series 1: Analysis. Vol. 2. Botanical Survey of India, Coimbatore. 258p.

Karthikeyan, S., Sanjappa, M., Moorthy, S., 2009. Flowering Plants of India-Dicotyledons. Volume 1. Acanthaceae Aviciniaceae). Botanical Survey of India, Kolkata. 365p.

Matthew, K.M., 1988. Further Illustrations on the Flora of the Tamilnadu Carnatic. Vol .4. The Diocesan Press, Madras. 915p.

Matthew, K.M., 1983. The Flora of the Tamilnadu Carnatic. Vol. 3 (Parts 1 and 2). The Diocesan Press, Madras. 2154p.

Matthew, K.M., 1982. Illustrations on the Flora of the Tamilnadu Carnatic. Vol.2. The Diocesan Press, Madras. $1027 p$.

Nair, N.C., A.N. Henry. 1983. Flora of Tamil Nadu, India. Series I: Analysis. Vol. 1. Botanical Survey of India, Coimbatore. 188p.

Pushpangadan, P., 1995. Ethnobotany in India - A Status Report All India Co-ordinated Research Project, Ministry of Environment and Forests. Government of India, New Delhi.

Rajkumar, G., Ravipaul, S., Sivasamy, A., Anuradha, G., Mohamed, S.R., 2014. Floristic composition and practices on the selected sacred groves of Perambalur District, Tamil Nadu. Int. J. Modn. Res. Rev. 2(11), 486-491.

Sanjappa, M., 1992. Legumes of India. Bishen Singh Mahendra Pal Singh, Dehra Dun. 338p.

\section{How to cite this article:}

Karthik, S., Subramanian, M., Ravikumar, S., Dhamotharan, R., 2016. Ethno-botanical study of selected sacred groves in Cuddalore and Villupuram Districts, Tamil Nadu, India. Int. J. Curr. Res. Biosci. Plant Biol. 3(1), 92-103. doi: http://dx.doi.org/10.20546/ijcrbp.2016.301.010 